\title{
Effect of dietary inclusion of Ginger (Zingiber officinale) and Garlic (Allium sativum) oil Mixture on the Growth Performance and Caecal Microbial Population of Broiler Chickens
}

Oluwafemi R.A. ${ }^{1}$, Halima Abdullahi ${ }^{1}$ and Alagbe, J.O. ${ }^{2 *}$

${ }^{1}$ Department of Animal Science, University of Abuja, Nigeria

${ }^{2}$ Department of Animal Nutrition and Biochemistry, Sumitra Research Institute, Gujarat, India.

*Corresponding author: Alagbe, J.O., Department of Animal Nutrition and Biochemistry, Sumitra Research Institute, Gujarat, India.

Received date: August 18, 2021; Accepted date: October 02, 2021; Published date: October 09, 2021

Citation: Oluwafemi R.A., Halima Abdullahi and Alagbe, J.O. (2021) Effect of dietary inclusion of Ginger (Zingiber officinale) and Garlic (Allium sativum) oil Mixture on the Growth Performance and Caecal Microbial Population of Broiler Chickens. J, Biotechnology and Bioprocessing 2(8); DOI: $10.31579 / 2766-2314 / 052$

Copyright: (C) 2021, Alagbe, J.O., This is an open access article distributed under the Creative Commons Attribution License, which permits unrestricted use, distribution, and reproduction in any medium, provided the original work is properly cited.

\begin{abstract}
The objective of the present study was to determine effect of dietary inclusion of (Zingiber officinale) and garlic (Allium sativum) oil mixture (GIGM) on the growth performance and caecal microbial population of broiler chickens. One hundred and fifty one-day-old broiler chicks (Ross 308) were randomly allocated into 5 treatments with three replicates consisting of 10 birds each in a completely randomized design. Birds in treatment 1 (T1) was fed basal diet with $0 \%$ inclusion of GIGM while T2, T3, T4 and T5 were given $0.1 \%, 0.2 \%, 0.3 \%$ and $0.4 \%$ respectively. Clean feed and water were offered ad libitum and all other management practices were strictly observed throughout the experiment which lasted for 56 days. Results obtained were used to determine weight gain (WG), average daily weight gain (ADWG), total feed intake (TFI), average daily feed intake (ADFI), feed conversion ratio (FCR) and microbial population of E.coli, Salmonella spp and Lactobacillus spp. ADWG, ADFI and FCR were significantly $(P<0.05)$ influenced by the dietary inclusion of GIGM. ADWG were highest in T5 (47.80 g), T4 (45.75 g) and T3 (45.09 g), intermediate in T2 $(39.59 \mathrm{~g})$ and lowest in T1 $(30.72 \mathrm{~g})$. Lactobacillus spp increased as the level of dietary inclusion of GIGM increases $(P<0.05)$. E.coli and Salmonella spp counts were significantly $(P<0.05)$ different among the treatments. It was concluded that GIGM could be included in the diet of broilers up to $0.4 \%$ without causing any deleterious effect on the performance and health of birds.
\end{abstract}

Keywords: poultry products, zingiber officinale, allium sativum, caecal microbial

\section{Introduction}

Consumer pressure for antibiotic free poultry products has led to increased research in the area of antibiotic alternatives, including essential oils. Essential oils (EOs) are plant based medicine that perform multiple biological activities such as; antimicrobial, antioxidant, antiviral, antiinflammatory, antifungal, antiviral and hepato-protective (Botslogou et al., 2002; Singh et al., 2021). According to Adewale et al. (2020); Musa et al. (2010), EOs are volatile oily liquids extracted from plant parts, such as flowers, buds, stems, seeds, leaves, twigs and root which are capable of producing a positive physiological function in the body of animals. All plant parts synthesize an extremely diverse range of chemical compounds (phytochemicals) which represent a great potential for the discovery and development of new pharmaceuticals [22]. Among the essential oil of high medicinal value are ginger (Zingiber officinale) and garlic (Allium sativum).
Ginger (Zingiber officinale) belongs to the family Zingiberaceae. It's essential oil had long served the purpose of being medically significant, as antifungal, antibacterial, anti-inflammatory analgesic and immunodulatory impacts due to the presence of minerals, vitamins, amino acids and phytochemicals ( $\beta$-bisabolene and zingiberene (major) other sesquiterpenes include zingiberol, $\alpha$-curcumence, $\beta$-sesquiphellandrene, $\beta$-sesquiphellandrol (cis and trans); numerous monoterpenchydrocarbons, alcohols and aldehydes) (Charles et al., 2000; Chang and Cheong, 2008; Alagbe and Oluwafemi, 2019).

Garlic (Allium sativum) contains sulfur compounds including alliin, produced enzymatically from (diallyl ehisosulfinate), allylpropyl disulfide, diallyl disulfide, diallyl trisulfide, ajoene and vicnyldithiines (secondary products of alliin produced non-enzymatically from allicin); S-allylmeracaptocystocysteine (ASSC) and S-methymeracaptocysteine (MSSC); terpens include citra, geranoil, linalool alfa and beta- 
phellandrene (Cheng et al., 2008; Demir et al., 2003). Previously, garlic oil has been listed as GRAS (Generally Recognized as Safe) (Olafadehan et al., 2020).

The efficacies of EOs are well documented both in vivo and in vitro (Dorman and Deans, 2000). According to Burt (2004), combination of essential oils has a greater antibacterial effect than individual EOs alone. EOs have been demonstrated to positively impact growth performance, blood profile and gut health of animals (Oluwafemi et al., 2021). However, there are inconsistencies in the results due to differences in the chemical composition of EOs, which are affected by plant age or part used, extraction or processing methods, geographical locations and antinutrients (Singh et al., 2021).

Therefore, this experiment was designed to evaluate the effects of dietary inclusion of ginger (Zingiber officinale) and garlic (Allium sativum) oil mixture on the growth performance and caecal microbial population of broiler chickens.

\section{Materials and methods}

\section{Experimental Site}

This study was carried out at the Department of Animal Science, University of Abuja Teaching and Research Farm, Main Campus, along airport Road, Gwagwalada, Abuja, Nigeria. Gwagwalada is the headquarters of the Gwagwalada Area Council located between latitudes $8^{\circ} 57^{1}$ and $88^{\circ} 55^{1} \mathrm{~N}$ and longitude $7^{\circ} 05^{1}$ and $7^{\circ} 06^{1} \mathrm{E}$ (Balogun, 2001).

\section{Sourcing and extraction of oil}

Fresh samples of ginger and garlic rhizomes were purchase from a local market in Gwagwalada Abuja, Nigeria. The samples were sorted out of the bad ones, then washed and peel manually with a kitchen knife to remove the outer covering of the rhizomes. It was dried for 14 days, milled into powder using a laboratory blender (Panasonic: Model 07A08C) and then stored in an air tight well label container for further analysis. The oil was extracted using soxhlet extraction procedure; $100 \mathrm{~g}$ of the sample were placed in a reflux condenser which consists of a condenser and a round bottom flask. The solvent used is petroleum ether and adjusted to $65^{\circ} \mathbf{C}$ to reach a vaporization point before the filtrate was exposed to the atmosphere and the residual solvent was allowed to evaporate before extracting the oil. The extracted oil was mixed in ratio 1: 1 to obtain ginger and garlic oil mixture (GIGLM).

\section{Experimental Animals and their management}

One hundred and fifty one day old (Ross 308) broiler chicks with mixed sex were used for the experiment. The birds were purchased from a commercial hatchery in Ibadan, Oyo State, Nigeria and weighed on arrival on the farm to obtain their initial body weight and thereafter weekly. A deep litter housing system was used for the experiment. Pens were fumigated two weeks prior to the commencement of the study, surroundings were cleaned and foot bath was made available to ensure strict biosecurity. Birds were divided to five treatments with 3 replicates of ten birds in a completely randomized design. Charcoal pots were used as source of heat and wood shavings serve as the litter material. Vaccines were administered according to the disease condition in the environment and all other management practices were strictly adhered to throughout the experiment which lasted for 56 days.

\section{Diet formulation}

Two basal diets were formulated at different stages of production to meet up with the requirements of birds according to NRC (1994) as presented in Table 1. Broiler starter's mash (1-28 days) and finishers mash (29-56 days). Birds in Treatment 1 (T1) was fed dietary inclusion of ginger and garlic oil (GIGLM) at $0 \%$, while T2, T3, T4 and T5 were fed $0.1 \%, 0.2$ $\%, 0.3 \%$ and $0.4 \%$ respectively.

\begin{tabular}{|l|l|l|}
\hline Ingredients & Starter phase (\%) & Finisher phase (\%) \\
\hline Maize & 50.00 & 55.00 \\
\hline Soya bean meal & 22.50 & 19.00 \\
\hline Groundnut cake & 15.00 & 12.00 \\
\hline Fishmeal (72 \%) & 2.00 & 2.00 \\
\hline Wheat offal & 4.45 & 6.05 \\
\hline Bone meal & 2.00 & 2.00 \\
\hline Limestone & 3.00 & 3.00 \\
\hline Salt & 0.25 & 0.35 \\
\hline Premix & 0.25 & 0.25 \\
\hline Methionine & 0.30 & 0.25 \\
\hline Lysine & 0.25 & 0.20 \\
\hline Total & $\mathbf{1 0 0 . 0}$ & $\mathbf{1 0 0 . 0}$ \\
\hline Calculated analysis (\% DM) & & \\
\hline Crude protein (\%) & 23.05 & 21.41 \\
\hline ME (Kcal/kg) & 2991.4 & 3100.3 \\
\hline Ether extract (\%) & 3.93 & 3.89 \\
\hline Crude fiber (\%) & 3.67 & 4.50 \\
\hline Calcium (\%) & 1.75 & 1.91 \\
\hline Phosphorus (\%) & 0.61 & 0.84 \\
\hline
\end{tabular}

*Premix supplied per kg diet: - vit A, 13,000 I.U; vit E, 5mg; vit D3, 3000I.U, vit K, 3mg; vit B2, 5.5mg; Niacin, 25mg; vit B12, 16mg; choline chloride, 120mg; Mn, 5.2mg; Zn, 25mg; Cu, 2.6g; folic acid, 2mg; Fe, 5g; pantothenic acid, 10mg; biotin, 30.5g; antioxidant, 56mg.

\section{Table 1 Composition of the experimental diets}

\section{Measurements}

\section{Performance paramaters}

Feed intake $(\mathrm{g})$ was determined by subtracting feed left over from feed served, it was estimated for each of the replicate daily.

Weight gain $(\mathrm{g})=$ final weight - initial weight
Feed to gain ratio $=$ feed intake $(\mathrm{g}) /$ weight gain $(\mathrm{g})$

Average daily weight gain $(\mathrm{ADWG})=$ Final body weight - Initial body weight

Total days of the experiment 
Average total feed intake $(\mathrm{ADFI})=\quad$ Feed intake

Total days of the experiment

\section{Caecal microbial enumeration}

On the $56^{\text {th }}$ day of the experiment, 6 birds were randomly selected per treatment for caecal microbial enumeration (E. coli, Salmonella spp and Lacobacillus spp). A 10-fold serial dilution method was used in which $1 \%$ peptone solution was mixed with caecal samples and poured unto agar plates (Model R4-02X, Punjab, India) and incubated at $37^{\circ} \mathrm{C}$ for 48 hours. Visible colonies were enumerated using colony counter and the results were expressed as $\log _{10} \mathrm{CFU} / \mathrm{g}$ of caecal digesta.

\section{Phytochemical analysis}

Phytochemical analysis of GIGM was carried out using standard methods described by Harbone (1973); Odebiyi and Sofowora (1978).

\section{Statistical analysis}

Data obtained were subjected to one -way analysis of variance (ANOVA) using SPSS (23.0) and significant means were separated using the software of the same package. Significant was declared if $\mathrm{P} \leq 0.05$.

\section{Results}

\section{Phytochemical composition of ginger (Zingiber officinale) and garlic (Allium sativum) oil}

The phytochemical composition of ginger (Zingiber officinale) and garlic (Allium sativum) oil (GIGM) is presented in Table 2. The sample contains flavonoids, saponins, terpenoids, phenols, oxalates, alkaloids and tannins at $20.78 \%, 6.10 \%, 12.71 \%, 17.90 \%, 2.04 \%, 10.31 \%$ and $9.44 \%$ respectively. In order of abundance flavonoids $>$ phenols $>$ terpenoids $>$ alkaloids $>$ tannins $>$ saponins $>$ oxalates.

\begin{tabular}{|l|c|}
\hline Constituents & Composition $(\%)$ \\
\hline Flavonoids & 20.78 \\
\hline Saponins & 6.10 \\
\hline Terpenoids & 12.71 \\
\hline Phenols & 17.90 \\
\hline Oxalates & 2.04 \\
\hline Alkaloids & 10.31 \\
\hline Tannins & 9.44 \\
\hline
\end{tabular}

Table 2 Phytochemical composition of ginger (Zingiber officinale) and garlic (Allium sativum) oil

Growth performance of broiler chickens fed dietary inclusion of ginger (Zingiber officinale) and garlic (Allium sativum) (GIGM) oil

Growth performance of broiler chickens fed dietary inclusion of ginger (Zingiber officinale) and garlic (Allium sativum) oil is presented in Table 3. Initial body weight (IBW) ranged from $42.80-43.10 \mathrm{~g}$, final body weight (1720.4 - $2720.0 \mathrm{~g})$, weight gain (1677.6 - $2677.0 \mathrm{~g})$, average daily weight gain (30.72 $-47.80 \mathrm{~g})$, total feed intake $(3880.3-4565.8 \mathrm{~g})$, average daily feed intake $(69.29-81.53 \mathrm{~g})$ and feed conversion ratio(1.50 - 2.72). WG, ADG, TFI and ADFI were highest in T3, T4 and T5 relative to the other treatments $(P<0.05)$. FCR were significantly different among the treatments $(P<0.05)$.

\begin{tabular}{|l|l|l|l|l|l|l|}
\hline Parameter & T1 & T2 & \multicolumn{1}{|c|}{ T3 } & \multicolumn{1}{|c|}{ T4 } & \multicolumn{1}{c|}{ SEM } \\
\hline IBW $(\mathrm{g})$ & 42.80 & 42.90 & 43.10 & 43.00 & 43.20 & 0.22 \\
\hline FBW $(\mathrm{g})$ & $1720.4^{\mathrm{c}}$ & $2260.1^{\mathrm{b}}$ & $2568.3^{\mathrm{a}}$ & $2605.1^{\mathrm{a}}$ & $2720.0^{\mathrm{a}}$ & 10.82 \\
\hline WG $(\mathrm{g})$ & $1677.6^{\mathrm{c}}$ & $2217.2^{\mathrm{b}}$ & $2525.2^{\mathrm{a}}$ & $2562.1^{\mathrm{a}}$ & $2677.0^{\mathrm{a}}$ & 9.44 \\
\hline ADG $(\mathrm{g})$ & $30.72^{\mathrm{c}}$ & $39.59^{\mathrm{b}}$ & $45.09^{\mathrm{a}}$ & $45.75^{\mathrm{a}}$ & $47.80^{\mathrm{a}}$ & 1.05 \\
\hline TFI & $4565.8^{\mathrm{a}}$ & $4243.8^{\mathrm{b}}$ & $4230.9^{\mathrm{b}}$ & $4031.4^{\mathrm{b}}$ & $3880.3^{\mathrm{c}}$ & 12.23 \\
\hline ADFI & $81.53^{\mathrm{a}}$ & $75.78^{\mathrm{b}}$ & $75.55^{\mathrm{b}}$ & $72.00^{\mathrm{b}}$ & $69.29^{\mathrm{c}}$ & 2.44 \\
\hline FCR & $2.72^{\mathrm{a}}$ & $1.91^{\mathrm{b}}$ & $1.70^{\mathrm{b}}$ & $1.60^{\mathrm{c}}$ & $1.50^{\mathrm{c}}$ & 0.12 \\
\hline
\end{tabular}

Means in the same row with different superscripts differ significantly $(P<0.05)$; T1: $0 \%$ GIGM; T2: $0.1 \%$ GIGM; T3: 0.2 \% GIGM; T4: 0.3 \% GIGM; T5: $0.4 \%$ GIGM; IBW: initial body weight; FBW: final body weight; WG: weight gain; ADG: average daily weight gain; TFI: total feed intake; ADFI: average daily feed intake; FCR: feed conversion ratio

Table 3 Growth performance of broiler chickens fed dietary inclusion of ginger (Zingiber officinale) and garlic (Allium sativum) (GIGM) oil

Caecal microbial population of broiler chicks fed diets with different level of GIGM

Caecal microbial population of broiler chicks fed diets with different level of GIGM is presented in Table 4. Microbial population of E. coli, Lactobacillus spp and Salmonella spp ranged from 20.12 - 34.98

\begin{tabular}{|l|c|c|c|c|c|c|}
\hline Parameters $\left(\log _{10}\right.$ CFU/g) & T1 & T2 & T3 & T4 & T5 & SEM \\
\hline E. coli & $34.98^{\mathrm{a}}$ & $25.10^{\mathrm{b}}$ & $23.98^{\mathrm{b}}$ & $23.18^{\mathrm{b}}$ & $20.12^{\mathrm{b}}$ & 1.30 \\
\hline Lactobacillus spp & $15.40^{\mathrm{c}}$ & $20.76^{\mathrm{b}}$ & $23.48^{\mathrm{b}}$ & $28.87^{\mathrm{b}}$ & $30.44^{\mathrm{a}}$ & 1.65 \\
\hline Salmonella & $29.09^{\mathrm{a}}$ & $19.32^{\mathrm{b}}$ & $19.04^{\mathrm{b}}$ & $18.58^{\mathrm{b}}$ & $18.20^{\mathrm{b}}$ & 0.96 \\
\hline
\end{tabular}

Means in the same row with different superscripts differ significantly $(P<0.05)$ $\left(\log _{10} \mathrm{CFU} / \mathrm{g}\right), \quad 15.40-30.44\left(\log _{10} \mathrm{CFU} / \mathrm{g}\right)$ and $18.20-29.09$ $\left(\log _{10} \mathrm{CFU} / \mathrm{g}\right)$. E. coli and Salmonella spp values were highest in T1 relative to other treatments $(P<0.05)$ contrary to Lactobacillus spp count where T5 was highest, T2, T3, T4 followed similar trend and lowest in T1 $(P<0.05)$. 


\section{Discussion}

The pharmacological importance of EOs is primarily due to bioactive chemicals in plant tissues as primary and secondary metabolites (Shittu and Alagbe, 2020; Dilfuza et al., 2015). These constituents have several therapeutic properties for instance terpenoids possess anticarcinogenic, antimalarial, anti-ulcer, antimicrobial or diuretic activity (Dudareva et al, 2004; Krishnaiah et al., 2007). Flavonoids in plants possess medicinal benefits which includes antioxidant and anti-inflammatory activities (Saxena et al., 2012; Ojewuyi et al., 2014). They have the ability to scavenge hydroxyl radicals, super oxide anions and lipid peroxy radicals (Okwu, 2004). Alkaloids perform antimalarial, antimicrobial, antioxidant and protection of plants from pathogens (Cushnie et al., 2014). Phenolic compounds show a wide range of pharmacological activities including anticancer, anti-inflammatory and prevention of cardiovascular diseases (Li et al., 2013).

The superior growth performance observed among birds in T3, T4 and T5 $(P<0.05)$ could be attributed to the essentials oils combination which exerted synergistic effects to prevent the consequence of intestinal inflammation (Lillehoj et al., 2018). Activities of phytochemicals in GIGM have also proven to stimulate functions of the intestinal tract to improve digestive secretions, nutrient absorption and metabolism (Alagbe and Oluwafemi, 2019). The dietary inclusion of GIGM in broilers also exerted a significant difference in feed intake $(P<0.05)$.

The activities of pathogenic bacteria in the caecum of the birds decreased as the dietary inclusion of GIGM increases $(P<0.05)$ across the treatments. This result agrees with the findings of Hyun et al. (2018); Singh et al. (2021); Adewale et al. (2021) who reported that phytochemicals such as flavonoids, phenols and alkaloids are capable of reducing the activities of pathogenic bacteria through competitive exclusion and promoting the proliferation of beneficial bacteria like Lactobacillus spp, thus playing a role of a probiotic. GIGM can act at different sites of the gastrointestinal tract (GIT) and relay on different targets such as modifying the intestinal microbial balance in favour of beneficial bacterial strains, colonization of the mucosa by adhering nonpathogens and occupation of specific receptors on mucosal surface (prebiotics) [23, Dierick et al., 2004).

\section{Conclusion}

It was concluded from this experiment that the use of essential oils (GIGM) is effective and effective and it represents one of the promising alternatives to antibiotics because it contains several secondary metabolites which performs several medicinal properties. Dietary inclusion of GIGM at $0.4 \%$ had a significant impact on growth as well as reducing the population of pathogenic bacteria without causing any deleterious effect on the performance and health of the animal.

\section{References}

1. Alagbe, J.O and Oluwafemi, R.A. (2019). Performance and haematological parameters of broiler chicks gives different levels of dried lemon grass (Cymbopogon citratus) and garlic (Allium sativum) extract. Research in: Agricultural and Veterinary Sciences. 3(2): $102-111$.

2. Burt, S. (2004). Essential oils: Their antibacterial properties and potential applications in food- A review. International Journal of Food Microbiology 94: 943-947.

3. Dormans, H.D and Deans, S.G (2000). Antimicrobial agents from plants: Antibacterial activity of plant volatile oils. Journal of Applied Microbiology 88: 308-316.

4. Alagbe, J.O., Shittu, M.D., Bamigboye, S.O and Oluwatobi, O. A. (2019). Proximate and mineral analysis of Pentasiplandra brazzeana stems bark. Electronic Research Journal of Engineering, Computer and Applied Sciences 1(2019): 91-99.
5. Adewale, A.O., Alagbe, J.O., Adeoye, Adekemi. O. (2021). Dietary Supplementation of Rauvolfia Vomitoria Root Extract as A Phytogenic Feed Additive in Growing Rabbit Diets: Haematology and serum biochemical indices. International Journal of Orange Technologies, 3(3): 1-12.

6. Alagbe, J.O and Oluwafemi, R.A. (2019). Growth performance of weaner rabbits fed noni (Morinda citrifolia) and Moringa olifera leaf mixture as partial replacement for soya bean meal. International Journal of Advanced Biological and Biomedicla Research 7(2): 185-195.

7. Alagbe, J.O (2020). Chemical evaluation of proximate, vitamin and amino acid profile of leaf, stem bark and root of Indigofera tinctoria. Eurpean Journal of Research Development and Sustainablility 1(1): 5-12.

8. Alagbe, J.O (2019). Proximate, mineral and phytochemical analysis of Piliostigma thonningii stems bark and roots. International Journal of Biological, Physical and Chemical Studies, 1(1): 1-7.

9. Balogun, O. (2001). The Federal Capital Territory of Nigeria: A Geography of Its Development. University of Ibadan Press Limited.

10. Cushnie, T.P.T., Cushnie, B and Lamb, A.J. (2014). Alkaloids: an overview of their antibacterial antibiotic enhancing and antivirulence activities. International Journal of Phytochemistry 44(5): 377-386.

11. Cheng, S., Liu, J.Y., Cheng, E.H and Cheng, S.T. (2008). Antifungal activity of cinnamaldehyde and eugenol congeners against wood rot fungi. Bioresource Technology, 99: 5145-5149.

12. Chang, K.J. and Cheong, S.H. (2008) Volatile organosulphur and nutrient compounds from garlic by cultivating areas and processing methods. Fed. Am. Soc. Exp. Bio. J. 22: 1108- 1112.

13. Charles, R., Garg, S.N and Kumar,S.(2000). New gingerdione from the rhizomes of Zingiber officinale fitolerapia.71:716-718.

14. Dudareva N, Pichersky E, Gershenzon, J. (2004) Biochemistry of plant volatiles. Plant Physiology 135: 1893-1902.

15. Dierick, N., Michiels, J and Van, N.C. (2004). Effect of medium chain fatty acids and benzoic acid as alternative for antibiotics on growth and some gut parameters in piglets. Communications in Agricultural and Applied Biological Sciences 69(2): 187-190.

16. Demir, E., Sarica, S., Ozcan, M.A. and Suicmez, M. (2003) the use of natural feed additives as alternatives for an antibiotic growth Promoter in broiler diets. Brazilian Journal of Poultry Science. 44: 44-45.

17. Harborne, J. D. (1973). Phytochemical methods: A guide to modern techniques of plant analysis. Chapman and Hall, London. 279.

18. Shittu, M.D and Alagbe, J.O (2020). Phyto-nutritional profiles of broom weed (Sida acuta) leaf extract. International Journal of Integrated Education 3(11): 119-124.

19. Saxena M, Saxena J, Nema R, Singh D, Gupta, A. (2013). Phytochemistry of Medicinal Plants. Journal of Pharmacognosy and Phytochemistry Center for Microbiology and Bio-Technology Research and Training, Bhopal, India. 8192 (1): 168-182.

20. Krishnaiah, D., Sarbatly, R and Bono, A. (2007). Phytochemical antioxidants for health and medicine: A move towards nature. Journal of Biomedical Science 1(3): 97-104.

21. Li, S., Li, R.Y., Gan, F.L and Li, H.B. (2013). Antioxidant capacities and total phrnolic contents of infusions from 233 medicinal plants. Industrial Crop Products 51: 289-298.

22. Michiels, J., Missotten, J., Dierick, N and De Smet, S. (2005). In vitro effect of botanicals on gut flora of pigs. 30ste Studiedag van de Nederlandstalige Voedingsonderzoekers Merelbeke. 67-68.

23. Michiels, J., Missotten, J., Dierick, N and De Smet, S. (2005). In vivo degradation and in vivo passage kinetics of carvacol, thymol, 
eugenol and trans-cinnamaldehyde along the gastrointestinal tracts of piglets. Journal of Food and Agriculture 88: 2371-2381.

24. Musa, B., Alagbe, J.O., Adegbite Motunrade Betty, Omokore, E.A. (2020). Growth performance, caeca microbial population and immune response of broiler chicks fed aqueous extract of Balanites aegyptiaca and Alchornea cordifolia stem bark mixture. United Journal for Research and Technology, 2(2):13-21.

25. National Research Council (1994). Nutrient requirement of poultry $9^{\text {th }}$ Rev Edn, Washington D.C. National Academy Press.

26. Oluwafemi, R.A., Uankhoba, I.P and Alagbe, J.O. (2021). Effects of turmeric oil as a dietary supplements on the growth performance and carcass characteristics of broiler chicken. International Journal of Orange Technologies, 3(4): 1-9.

27. Oluwafemi, R.A., Uankhoba, I.P and Alagbe, J.O. (2021). Effects of turmeric oil as a dietary supplement on the haematology and serum biochemical indices of broiler chickens. Bioinformatics and Proteomics Open Access Journal 5(1): 000138.

28. Olafadehan, O.A., Oluwafemi, R.A and Alagbe, J.O. (2020). Carcass quality, nutrient retention and caeca microbial population of broiler chicks administered Rolfe (Daniellia oliveri) leaf extract as an antibiotic alternative. Journal of Drug Discovery. 14(33):146-154.
29. Olafadehan, O.A., Oluwafemi, R.A and Alagbe, J.O. (2020). Performance, haemato-biochemical parameters of broiler chicks administered Rolfe (Daniellia oliveri) leaf extract as an antibiotic alternative. Advances in Research and Reviews, 2020, 1:4.

30. Ojewuyi, O.B, Ajiboye, T. O, Adebanjo, E. O, Balogun, A, Mohammed, A.O. (2014). Proximate composition, phytochemical and mineral contents of young and mature Polyalthia longifolia Sonn.leaves. Fountain Journal of Natural and Applied Sciences: 2014; 3(1): $10-19$.

31. Odebiyi, A. and Sofowora, A. E. (1978). Phytochemical Screening of Nigerian Medicinal Plant. Part III, Lloydia, 41, 234 246.

32. Okwu, D.E. (2004). Phytochemical and vitamin content of indigenous spices of South Eastern Nigeria Journal of Sustainable Agriculture and Environment 6:30-37.

33. Singh, A.S., Alagbe, J.O., Sharma, S., Oluwafemi, R.A and Agubosi, O.C.P. (2021). Effect of dietary supplementation of melon (Citrallus linatus) seed oil on the growth performance and antioxidant status of growing rabbits. Journal of Multidimensional Research and Reviews, 2(1): 78-95.
This work is licensed under Creative Commons Attribution 4.0 License

To Submit Your Article Click Here: Submit Manuscript

DOI: $10.31579 / 2766-2314 / 052$
Ready to submit your research? Choose Auctores and benefit from:

$>$ fast, convenient online submission

$>$ rigorous peer review by experienced research in your field

$>$ rapid publication on acceptance

$>$ authors retain copyrights

$>$ unique DOI for all articles

$>\quad$ immediate, unrestricted online access

At Auctores, research is always in progress.

Learn more https://auctoresonline.org/journals/biotechnology-andbioprocessing 